\title{
Da história das mulheres ao cinema brasileiro de autoria feminina'
}

\section{From women's history to Brazilian women's filmmaking}

\author{
Karla Holanda \\ Cineasta e professora doutora do Bacharelado em Cinema e Audiovisual e do PPG em Artes, Cultura e Linguagens do Instituto \\ de Artes e Design da Universidade Federal de Juiz de Fora. \\ $<$ holanda.k@gmail.com>
}

\section{RESUMO}

As mulheres têm feito menos filmes que os homens, embora cada vez produzam mais. Ainda assim, muitos de seus filmes foram ignorados ou receberam pouca atenção. Para compreender esse desequilíbrio, este artigo faz um painel sobre a secular discriminação da mulher na sociedade. Igualmente demonstra que sempre houve resistência das mulheres a essa subjugação. Nosso objetivo é reforçar a razão de se destacar filmes feitos por mulheres, afinal na história do cinema, assim como na história em geral, como defende Joan Scott, a parte concernente às mulheres não está suficientemente contemplada. Em seguida, apresentamos e discutimos três filmes pouco conhecidos da história do cinema brasileiro, mesmo que tragam elementos estilísticos, históricos e temáticos contundentes - A entrevista (Helena Solberg, 1966), Os homens que eu tive (Tereza Trautman, 1973) e Feminino Plural (Vera de Figueiredo, 1976).

\begin{abstract}
Women have made fewer films than men, although increasingly they produce more. Still, many of their films were ignored or given little attention to. To understand this imbalance, this article is a panel on the secular discrimination of women in society. It also shows that there has always been resistance to this subjugation of women. Our goal is to strengthen the reason why films made by women stand out at all in the history of cinema, as well as in history in general, as advocated by Joan Scott, the part concerning women is not sufficiently covered. Next, we present and discuss three films little known in the history of Brazilian cinema, even if they bring stylistic elements, historical and thematic damning - A entrevista (Helena Solberg, 1966), Os homens que eu tive (Tereza Trautman, 1973) e Feminino Plural (Vera de Figueiredo, 1976).
\end{abstract}

Keywords: Communication. Cinema. Feminism.

No Hebdo-Latin um estudante declarava há dias: "Toda estudante que consegue uma posição de médico ou de advogado rouba-nos um lugar". Esse rapaz não duvidava, um só instante, de seus próprios direitos sobre o mundo. Não são somente os interesses econômicos que importam. Um dos benefícios que a opressão assegura aos opressores é de o mais humilde destes se sentir superior: um "pobre branco" do sul dos E.U.A. tem o consolo de dizer que não é "um negro imundo" e os brancos mais ricos exploram habilmente esse orgulho. Assim também,

1 Este texto é resultado da pesquisa do projeto "Documentário de autoria feminina no Brasil", apoiado pelo Conselho Nacional de Desenvolvimento Científico e Tecnológico - CNPq. 
o mais medíocre dos homens julga-se um semideus diante das mulheres (Simone de Beauvoir, em O segundo sexo, 1949).

A experiência de assistir ao filme A entrevista (1966), de Helena Solberg, me provocou euforia de arqueólogo diante da descoberta de um fóssil. Afinal, em 2014 me é revelado um filme feito 48 anos antes, tão diferente de tudo que se conhecia até aquele momento no Brasil e dirigido por uma mulher. Fato que não é detalhe. Que filme era aquele? Onde eu estava que perdi as discussões, os ensaios, as críticas, as aulas que inseriam esse filme no panteão do documentário moderno brasileiro? Saí da sessão do Festival É Tudo Verdade - que fez a primeira retrospectiva da diretora no país - querendo discutir o filme, buscando ler sobre ele: procurei artigos, teses, consultei enciclopédias, colegas... quase nada. $O$ que encontrei era muito distante do tamanho do filme. $O$ assombro se somou à recente descoberta de Feminino Plural (1976), da Vera de Figueiredo. Vera quem...? - perguntaram muitos. E o que dizer de Os homens que eu tive (1973), da Tereza Trautman? E os inúmeros filmes da Eunice Gutman...? E quem viu, além de Bernardet ${ }^{2}$, o inconvencional Indústria (1969), de Ana Carolina? Onde estão às experiências audiovisuais de Lygia Pape e Suzana Amaral, iniciadas nos 1960 ? E as obras e estudos sobre as pioneiras da videoarte, Letícia Parente, Sônia Andrade, Anna Bella Geiger...? Todas essas descobertas pessoais tão pouco aprofundadas mostravam-se tijolos soltos, não cimentados, na construção da historiografia do cinema brasileiro.

De acordo com o catálogo Documentário Brasileiro, somente na década de 1960 começam a surgir os primeiros documentários dirigidos por mulheres no Brasil. Exclusivamente dirigidos por mulheres encontramos apenas oito títulos. Para se ter ideia do disparate da relação com a produção masculina, o mesmo catálogo aponta nessa década 225 documentários dirigidos exclusivamente por homens ${ }^{3}$.

É certo, que se pode dizer que, há toda uma produção feita por mulheres ou homens, sejam negros, brancos, homossexuais, heterossexuais, moradores do centro do país ou de periferias, feita em $35 \mathrm{~mm}, 16 \mathrm{~mm}$, superoito ou vídeo que, igualmente, reverberou pouco na história do cinema, mas negar a trajetória

2 Há anos esse filme não dispõe de cópias. O que se sabe sobre o filme costuma vir das análises de Jean-Claude Bernardet, em seu livro Cineastas e imagens do povo (1985).

3 Mesmo que essa catalogação não seja definitiva, uma vez que novos filmes podem ser descobertos e inseridos, dificilmente a proporção será diferente. Disponível em: <http://documentariobrasileiro. org >. Acesso em: 10 mar. 2016. 
de opressão e invisibilidade das mulheres (e de sua resistência) ao longo da história demonstra desinteresse por preocupações teóricas não androcêntricas.

Nesse sentido, antes de discutir três filmes de autoria feminina, pouco conhecidos e que só recentemente suas histórias estão sendo recuperadas ( $A$ entrevista, Feminino Plural e Os homens que eu tive), traçarei um percurso da história das mulheres que permita, nas entrelinhas, pensar questões, como: por que destacar filmes feitos por mulheres? Na história do cinema brasileiro já não está contemplada a história do cinema feito por mulheres?

\title{
A mulher na sociedade ocidental e o movimento feminista - breves notas
}

Desde Aristóteles, é construído um pensamento que naturaliza a subordinação das mulheres (e, no caso, também dos escravos) na estruturação da sociedade. Em "A política", o filósofo diz:

\begin{abstract}
A natureza, tendo em conta a necessidade da conservação, criou uns seres para mandar e outros para obedecer [...]. A natureza fixou, por conseguinte, a condição especial da mulher e a do escravo. [...] Entre os bárbaros, a mulher e o escravo estão numa mesma linha, e compreende-se a razão de ser: a natureza não criou entre eles um ser destinado a mandar (Aristóteles, 1965, citado por Pereira, 2014, p. 31).
\end{abstract}

Se Aristóteles "demonstra" que a autoridade é natural, o discurso teológico vem dizer que ela é divina. A própria explicação da Bíblia para a origem do universo reforça a ideia de superioridade masculina, ao considerar Eva um "presente de Deus a Adão, nascida de sua costela" e "responsável pelo pecado original e perdição do mundo" (Pereira, 2014, p. 34).

Na palavra de Cristo não se encontra nenhuma menção à supremacia masculina - ao contrário, sua mensagem é de que marido e mulher são iguais. Ao pregar o amor ao próximo, punha "um freio à autoridade, de onde quer que viesse". No entanto, teólogos obscureceram-nas, moldando-as como lhes convinham os interesses, como diz Badinter (1985). São Paulo proclama aos Coríntios:

A cabeça de todo o homem é Cristo, a cabeça da mulher é o homem e a cabeça de Cristo é Deus [...]. O homem não deve cobrir a cabeça porque é imagem e glória de Deus; a mulher, porém, é glória do 
homem [...] (Primeira Epístola aos Coríntios 11:3-9, na Bíblia Sagrada, citada por Pereira, 2014, p. 34).

Contudo, pela palavra de Cristo, a Igreja proclamou certa igualdade, o que garantiu alguns direitos a algumas mulheres (as das classes superiores): na França, por exemplo, até o século XIII, a mulher podia administrar sua fortuna e alienar seus bens com o consentimento do marido, mover ações judiciais, ter um feudo e substituir o marido em caso de doença. Mas com o desenvolvimento do direito romano na França, os direitos econômicos das mulheres se restringem tanto a partir do século XIV que quase nada restará deles dois séculos depois. Ainda segundo Badinter, o vocabulário e as crenças habituais em relação às mulheres evocavam ideias concebidas por críticas contra elas que abundaram a partir do século IV, muitas baseadas em Santo Agostinho, como o texto Songe de Verger (livro 1, cap. CXLVII), escrito no final da Idade Média: “Um animal que não é firme, nem estável, odioso, que alimenta a maldade... ela é fonte de todas as discussões, querelas e injustiças". Textos semelhantes se multiplicaram nessa época e, progressivamente, a acusação de malignidade natural da mulher vai cedendo espaço à ideia de fraqueza e invalidez (Badinter, 1985).

Politicamente, a Carta Magna (Inglaterra, 1215), ao restringir os poderes do rei, submetendo-o à fiscalização, se torna um marco fundador dos direitos humanos. Sua importância, entretanto, "concentra-se essencialmente no estatuto proibitivo, face ao poder tirânico do monarca, e não tanto nas suas afirmações e permissões". Somente quatro séculos mais tarde, o conceito de "homens livres" se estende a todos os ingleses, restringindo-se ainda aos elementos do sexo masculino - Guilherme de Orange, em 1689, proclama a Bill of Rights, declaração de direitos elaborada pelo Parlamento inglês. Porém, mais uma vez, segundo Pereira, são proclamadas liberdades que vão regular a relação do Parlamento com a Coroa e não tratar de liberdades individuais. No século seguinte (1776), o Congresso norte-americano adota a Declaração de Independência dos Estados Unidos, que consagra a igualdade entre todos os homens. Thomas Jefferson redige os direitos à liberdade, à vida e à felicidade. Semanas antes, fora proclamada a Declaração de Direitos da Virgínia, documento que serviu de base à Declaração de Independência. Em 1789, é a vez da Declaração dos Direitos do Homem e do Cidadão, na Revolução Francesa, que inaugura a Idade Moderna (Pereira, 2014).

A ideia de um papel "natural" para a mulher é reforçada por Jean-Jacques Rosseau, sobretudo em seu livro Émile (1762), onde cristaliza características 
femininas "natas", como "ser boa mãe, servir e agradar ao homem, não pensar nem agir" (Telles, 2012, p. 80). A obra deu "impulso inicial à família moderna, isto é, a família fundada no amor materno" (Badinter, 1985, p. 53).

Resistência das mulheres sempre houve ao longo da história. Para ficar em torno só da Revolução Francesa, por exemplo, pode-se lembrar de Olympe de Gouges que, em resposta à Declaração francesa, redigiu um projeto de Declaração dos Direitos da Mulher e da Cidadã, onde, dentre outros itens, as mulheres teriam direito à liberdade de expressão e, portanto, a revelar a identidade dos pais de seus filhos, concedendo aos bastardos os mesmos direitos que os legítimos. 0 projeto lhe fez merecer a condenação à morte na guilhotina, em 1793. No ano anterior, no Reino Unido, Mary Wollstonecraft publica $A$ vindication of the rights of woman. O livro exige uma igualdade de oportunidades educativas entre os sexos e critica o ideal submisso da feminilidade, o que valeu à autora obscenas caricaturas e o apelido de "hiena de anáguas" (Pereira, 2014, p. 40). Em 1832, 40 anos depois da publicação de Wollstonecraft, seu livro é traduzido livremente no Brasil por Nísia Floresta, resultando na obra Direito das mulheres e injustiça dos homens. Floresta também sofreu pressões e deixou o Brasil devido à oposição que sua atuação como professora e escritora despertou (Telles, 1985).

Entre o final do século XVIII e o início do XX, centram-se as lutas pelos direitos civis da população feminina, como o direito ao voto e ao salário igual ao do homem na realização do mesmo trabalho, bandeiras que marcaram a chamada primeira onda do feminismo e que foram inspiradas nos ideais de igualdade, liberdade e fraternidade da Revolução Francesa (Pereira, 2014).

Com a conquista de direito ao voto feminino em muitos países na primeira metade do século XX e, sobretudo, com a publicação de O segundo sexo (1949), de Simone de Beauvoir, pavimenta-se a segunda onda do feminismo. No livro, pela primeira vez na história da humanidade, se diz que a igualdade de direitos não se dá somente no acesso à esfera pública, mas inevitavelmente inicia-se na vida privada (Pereira, 2014). Outra publicação emblemática é Mística feminina (1963), de Beth Friedan, que revelaria inúmeras mulheres insatisfeitas ou deprimidas com suas funções exclusivamente reprodutiva e educativa dentro da família. Essa onda será marcada por contestações ao modelo de feminilidade que naturalizava o papel submisso das mulheres, submetendo-as ao domínio masculino, e terá seu ápice na década de 1970 (Cavalcante e Holanda, 2013).

Estamos, atualmente, no que seria a terceira onda, que traz os estudos de gênero para os estudos das mulheres e que contesta a tentativa de se referir a todas as mulheres de forma igualitária. No tópico seguinte, são abordadas algumas dessas questões. 
A função deste tópico foi fazer um panorama bastante horizontal sobre a discriminação do tratamento da mulher na sociedade, que buscou justificativa em infundadas ideias de natureza e divindade para lhes reservar funções secundárias. A resistência das mulheres custou a elas punições, incluindo a própria vida. Suas atividades e ações foram desprezadas ou ridicularizadas. Apesar disso, a mulher tem participação em praticamente todas as áreas, embora pouco refletida. Na literatura, por exemplo, é grande o número de estudos que busca recuperar escritoras de séculos passados ignoradas pela história ou, a elas atribuída menor importância. $O$ cinema é a mais recente das artes e já acumula histórias de cineastas esquecidas, a começar pela primeira da história do cinema, Alice Guy Blaché, que realizou centenas de filmes entre 1896 e 1920 e, apesar disso, é alarmante a pouca quantidade de estudos que há sobre ela ainda hoje (Pereira, 2014).

\section{A história das mulheres dentro da história e a diferença sexual}

O surgimento da história das mulheres como um campo de estudo, diz Joan Scott (1992), está relacionada às campanhas feministas para a melhoria das condições de trabalho. Ela expandiu os limites da história, mas há uma incômoda ambiguidade por ser "um suplemento inócuo à história estabelecida e um deslocamento radical dessa história" (Scott, 1992, p. 75). A história das mulheres se confronta com "o dilema da diferença" desde que o sujeito da moderna historiografia ocidental foi incorporado com frequência como um homem branco. O "universal" (homem branco) implica numa comparação com o específico (Scott, 1992, p. 77). Desestabilizando padrões consolidados, ao intentar destaque das mulheres na história, a história das mulheres questiona a prioridade dada à "história do homem" e implicitamente implica nas indagações:

\footnotetext{
Através de que processos as ações dos homens vieram a ser consideradas uma norma, representativa da história humana em geral, e as ações das mulheres foram subestimadas, subordinadas ou consignadas a uma arena particularizada, menos importante? [...] Qual é o efeito sobre as práticas estabelecidas da história de se olhar os acontecimentos e as ações pelo lado de outros sujeitos, as mulheres, por exemplo? Qual o relacionamento entre o historiador e os sujeitos sobre os quais ele/ela escreve? (Scott, 1992, p. 78).
}

Michel de Certeau (1986), citado por Scott (1992, p. 79), traz a pergunta "uma mulher produz uma historiografia diferente daquela do homem?" Sua 
indagação não está interessada numa resposta, mas colocar em questão o lugar do sujeito, abalando a crença da construção de verdade baseada na irrelevância do narrador. Com isso, de acordo com Scott, Certeau não enfatiza que só as mulheres possam escrever a história das mulheres, mas revela que essa história traz "à luz as questões de domínio e objetividade sobre as quais as normas disciplinares são edificadas", o que sugere que a história como está é incompleta e "o domínio que os historiadores têm do passado é necessariamente parcial" (Scott, 1992, p. 79).

A história das mulheres, de acordo com Scott (1992), considerou "as mulheres" uma categoria social fixa, cuja essência era inalterável, e afirmava a distinção da "cultura das mulheres". O discurso da identidade coletiva produziu uma experiência feminina compartilhada, enfatizando a sexualidade como ponto comum, o que contribuiu para o movimento nos anos 1970. Esse aumento da consciência levou "à descoberta da 'verdadeira' identidade das mulheres, a queda das viseiras, a obtenção de autonomia, de individualidade e, por isso, de emancipação" (Scott, 1992, p. 85). O antagonismo homem/mulher foi central na história e na política, diz Scott. Mesmo quando se deu atenção à diversidade, à classe, à raça e à cultura, o que produziu variação sobre o tema do patriarcado, manteve-se fixa a oposição. A oposição direta entre esses dois grupos parecia resolver a ambiguidade da história das mulheres. Podia-se dizer que a afirmação e a experiência separada das mulheres é que deu legitimidade à história das mulheres como empreendimento histórico. Mesmo assim, a história das mulheres não fez parte das preocupações dominantes da história (Scott, 1992).

Entretanto, no final dos anos 1970, a viabilidade da categoria mulheres foi desafiada e a diferença passou a ser um problema a ser analisado. Ao estabelecerem a identidade separada das mulheres, o objetivo daqueles historiadores era integrar as mulheres à história. Mas a integração mostrouse difícil de ser atingida. Scott (1992) diz que os historiadores acharam difícil inscrever as mulheres na história e reescrever a história exigia reconceituações e um modo de pensar sobre a diferença que eles não estavam preparados. "Gênero" foi o termo usado para teorizar a questão da diferença sexual - as feministas enfatizaram as questões sociais de gênero ao invés das conotações físicas do sexo e também o aspecto relacionado do gênero: só se pode conceber mulheres se elas forem definidas em relação aos homens e vice-versa. A política de identidade dos anos 1980 trazia questionamentos que argumentavam que as diferenças fundamentais da experiência (mulheres negras, mulheres 
judias, mulheres lésbicas, mulheres trabalhadoras pobres, mães solteiras, etc.) impossibilitavam a reivindicação por uma identidade isolada (Scott, 1992).

Diante de tantas diferenças (classe, raça, etnia, sexualidade), qual o campo comum em que as feministas podem organizar uma ação coletiva coerente? Denise Riley acredita que é possível organizar-se politicamente com categorias instáveis, no que Scott concorda. Isso tem sido feito, diz Scott, mas como ser feito ainda necessita de discussão (Scott, 1992).

A primeira limitação da "diferença sexual" como sustentação para a teoria feminista, na definição do conceito de gênero, segundo De Lauretis (1994), é por confinar o pensamento crítico feminista a um arcabouço conceitual estruturado numa oposição entre dois sexos, tornando difícil "articular as diferenças entre mulheres e Mulher, isto é, as diferenças entre as mulheres ou, talvez mais exatamente, as diferenças nas mulheres" (De Lauretis, 1994, p. 208). Entendendo que o "potencial epistemológico radical do pensamento feminista" significa a possibilidade de entender que o sujeito é

[...] constituído no gênero, sem dúvida, mas não apenas pela diferença sexual, e sim por meio de códigos linguísticos e representações culturais; um sujeito "engendrado" não só na experiência de relações de sexo, mas também nas de raça e classe; um sujeito, portanto, múltiplo em vez de único, e contraditório, em vez de simplesmente dividido (De Lauretis, 1994, p. 208).

De Lauretis diz que esse potencial epistemológico já é emergente nos escritos feministas dos anos 1980 e que a segunda limitação do conceito de "diferença sexual" está em que ele tende a reacomodar tal potencial (ou seja, o pensamento feminista) aos termos do próprio patriarcado ocidental, inclinando-se a reproduzir os discursos culturais dominantes, "mesmo nas reescritas feministas das narrativas culturais" (De Lauretis, 1994, p. 207-208). O que a autora defende é que seja construído um novo conceito de gênero que não esteja tão vinculado à diferença de gênero.

O cinema, assim como a narrativa e a teoria, é tecnologia de gênero, segundo De Lauretis (1994). Mas pode parecer paradoxal pensar assim da teoria, diz ela, uma vez que as teorias existentes não se preocupam com o gênero (Althusser, Foucault, Kristeva, Eco) ou se se preocupam com o gênero, não são capazes de conceber um sujeito feminino (como a psicanálise de Freud) ou o deixam "atolado nos pântanos do patriarcado". Entretanto, seu argumento é que "tanto as teorias quanto as ficções nela inspiradas contém e promovem certas 
representações de gênero, assim como faz o cinema" (De Lauretis, 1994, p.228). A autora diz que foi capaz de entender o cinema e as teorias narrativas como tecnologias de gênero não apenas por determinadas leituras, mas também porque absorveu por experiência pessoal, "o método analítico e crítico feminista, a prática da autoconscientização", com o qual é capaz de apreender a realidade social a partir de sua conscientização de gênero. Sua terceira proposição discutida no texto aqui referenciado consiste em que a construção do gênero se dá via tecnologias de gênero e que os termos para uma construção diferente dos gêneros podem existir nas margens do discurso hegemônico - "propostos de fora do contrato social heterossexual", os efeitos de tais termos "ocorrem ao nível 'local' de resistências, na subjetividade e na auto-representação" (De Lauretis, 1994, p. 231).

Neste tópico, vimos como a disciplina "história" parece ter tratado da história da metade da humanidade, ao se centrar na história de um dos "gêneros". É essa a razão de ter sido desenvolvido um campo de estudo dentro da disciplina, a "história das mulheres", para abranger a outra metade. Criticando a visão dominante, predominantemente masculina, a história das mulheres desestabilizou os padrões adotados pela história tradicional, como considerar sujeito "universal" o homem branco. Se num primeiro momento, a marcação da diferença sexual e a oposição homem/mulher foram importantes para legitimar esse campo da história e para os estudos feministas, logo se mostraram limitadas. Primeiro porque parecia que todas as mulheres estavam reunidas em torno das mesmas questões em um ser uno quando, na verdade, havia (há) interesses variados. Depois, o conceito que parte da diferença sexual pode desarmar o potencial epistemológico do pensamento feminista emergente desde os anos 1980, que consiste em compreender o sujeito engendrado nas relações também de raça e classe, não só na sexual. O risco é que esse potencial seja reacomodado dentro do discurso patriarcal. O que se defende, portanto, é que seja criado um novo conceito de gênero, que não dependa tanto da diferença sexual. $\mathrm{O}$ assunto não está encerrado - talvez nunca vá a estar -, demonstrando a complexidade e a dinâmica do processo.

A seguir, comento três filmes dirigidos por mulheres no Brasil e pouco citados na história do cinema brasileiro e que só recentemente começam a ter certa visibilidade.

\section{A entrevista (Helena Solberg, 1966)}

No final dos anos 1950, surgem os primeiros documentários no Brasil que inauguram o cinema moderno brasileiro - ou o cinema novo. Filmes 
como Arraial do Cabo (Paulo César Saraceni e Mário Carneiro, 1959), Aruanda (Linduarte Noronha, 1960), Couro de gato (Joaquim Pedro de Andrade, 1960), Memória do cangaço (Paulo Gil Soares, 1964), Maioria absoluta (Leon Hirszman, 1964), Viramundo (Geraldo Sarno, 1965), A opinião pública (Arnaldo Jabor, 1967), dentre muitos outros, estão no cânone desse período. Embora, de certa forma, influenciados pelos métodos que faziam história nos Estados Unidos, com um documentário que acreditava desvelar a realidade diante de si (cinema direto), e na França, com a interação do cineasta e da equipe na cena, como a criar determinada realidade (cinema verdade), a característica maior desses filmes brasileiros foram os temas, corpos, figurinos e locações marcados pela dura realidade social e que propunham discutir o país, dando voz ao "povo". Contrariamente aos modelos norte-americano e francês, os cineastas brasileiros não continham o ímpeto de diagnosticar o país e sua população através de uma voz off que realinhava qualquer tentativa de ambiguidade ou paroxismo. Ímpeto que se justifica, afinal, imagens desse Brasil profundo eram muito recentes, a desigualdade social alarmava, era preciso fazer (ou dizer ou ensinar) algo.

No entanto, A entrevista, filme não abordado pela historiografia do cinema brasileiro, vai na contramão dessa tendência que predominou até então. Nesse curta de 19 minutos, a diretora opera ela mesma um gravador Nagra, reunindo vozes de várias moças de classe média alta, entre 19 e 27 anos, que falam de dilemas caros à época, como o papel da mulher na sociedade, entre o que se espera delas e o pensamento ainda em construção sobre sexo, casamento, virgindade, formação profissional, emancipação.

Vale destacar alguns trechos, que são ditos em off - só na cena final há som sincrônico, quando a cunhada da diretora (Glória Solberg), que faz o papel de uma noiva no dia de seu casamento enquanto ouvimos os depoimentos, fala diretamente. As outras mulheres não concordaram em revelar suas identidades. Os depoimentos variados são montados em blocos, por vezes, construindo um discurso contraditório:

Você vai ter que dosar, vai ter que se inibir conscientemente, sabendo que você está fazendo aquilo com um fim, entende? [...] Mas pra mim, eu preferiria casar virgem, ter relação sexual já casada. [...] Em muitas horas eu acho que pecar contra a castidade é uma obrigação.

Eu gosto muito de liberdade, liberdade que acho que não teria no casamento [...], tenho horror de ser dominada por um homem. [...] Eu acho que a independência exagerada da mulher, da maneira que 
a mulher está querendo tomar, não dá certo porque, inclusive, têm mulheres que se destacam de tal forma que não deixam o homem numa situação muito confortável. [...] Se eu não tivesse casado, acho que estaria eternamente infeliz, não satisfeita comigo mesma.

Eu acho que a mulher deve saber línguas, deve ser socialmente perfeita [...] [Deve] estar sempre em dia com o que acontece no mundo; ela precisa ler muito, ter uma cultura muito grande. Mas ela não precisa se dedicar a uma coisa; ela pode encher a vida dela com aulas, com conferências, uma série de coisas, mas não se dedicar a um trabalho (A entrevista, 1966).

Os temas abordados no filme são inéditos no cinema - talvez não só no brasileiro. Essas questões estão no centro do livro de Betty Friedan, Mística feminina (1963), que abalara as certezas do mundo patriarcal em relação à satisfação das mulheres diante daquela divisão de papeis na sociedade, ao expor depoimentos de centenas de mulheres que se debatiam entre sua realidade e a imagem à qual tinham que se moldar. O livro de Friedan fora publicado apenas três anos antes do filme de Solberg, o que demonstra o quanto assunto dessa natureza já mobilizava a diretora, que a essa altura não só já havia também lido O segundo sexo (1949), de Simone de Beauvoir, como já havia entrevistado a escritora, em visita ao Brasil no começo dos 1960 (Holanda, 2015).

Entretanto, o que mais surpreende no fato do filme de Solberg não ter sido considerado pela história do cinema desse período, é a não discussão do modelo de ruptura em relação à voz off como fio condutor da narrativa, que predominava nos documentários da época. As vozes que permeiam o filme, em off, são variadas e contraditórias, valorizando a pluralidade de pensamentos e justamente enfatizando a ambiguidade. Não havia pretensão em afirmar uma verdade única, nem em interpretar determinadas realidades ou sentidos. Ao contrário, o filme foge de qualquer tom doutrinário. Isso não é nada pouco relevante no contexto do documentário brasileiro de meados dos anos 1960 (Holanda, 2015).

Depois desse filme de estreia, Helena Solberg realizou ainda no Brasil um curta em 1970, Meio-dia. No ano seguinte, vai morar nos Estados Unidos, onde permanecerá por três décadas e suas primeiras produções nesse país são com temáticas feministas: The emerging woman (1974), The double day (1975) e Simplesmente Jenny (1977). Seu filme mais conhecido talvez seja Carmen Miranda: bananas is my business (1994). Mais recentemente, já de volta ao Brasil, realizou entre 2004 e 2013, Vida de menina e A alma da gente (Tavares, 2014). 


\section{Os homens que eu tive (Tereza Trautman, 1973)}

Tereza Trautman tinha 22 anos, quando lançou seu primeiro longa metragem, Os homens que eu tive. Trautman, também roteirista, criou a personagem Pity pensando em Leila Diniz para interpretá-la. Mas, com a inesperada morte da atriz em 1972, Darlene Glória a substituiu. Pity é uma jovem de classe média carioca, casada com Dôde. Eles têm uma proposta de vida livre, cada um tem outros parceiros. Os amantes de Pity são amigos de Dôde, bebem juntos e até dividem a mesma casa. Embora Dôde também tenha amantes, nós não as conhecemos, uma vez que a narrativa é inteiramente sob o ponto de vista de Pity. A naturalidade dos arranjos parece ser a tônica, não há surpresas, nem cobrança, há respeito e aceitação. A harmonia só é quebrada quando Pity se apaixona por Peter, um novo amante, com quem passa a dividir mais tempo. $O$ casamento se desfaz. A raiva inicial logo cede lugar à compreensão de ambos. Dôde vai visitá-la na casa de Peter, com quem está morando agora. Mas logo Pity se cansa de certa indiferença de Peter e vai morar com uma amiga. Em seguida, as duas vão morar com Torres, um artista que abriga outros artistas numa espécie de república, em Santa Teresa. Uma característica importante do filme, que Ana Veiga assinala, é a ausência de grandes conflitos, semelhante aos filmes de Agnés Varda (Veiga, 2013).

Na república, Pity tem outros casos, incluindo a única cena de sexo em que o casal aparece despido, um encontro casual com um desconhecido e que, só ao final, ele pergunta o nome dela. E outra cena em que ela e a amiga Bia estão abraçadas sob lençóis, sugerindo que acabaram de ter relação sexual. Mas é com Torres que ela vai se envolver e decide ter um filho. Ao final, Dôde reaparece e os três estão juntos. Ela grávida, Dôde pede para que o bebê herde seu nome, afinal não se separaram oficialmente. Torres concorda, dando a entender que um novo triângulo se forma.

Um filme que traz uma protagonista feminina e cujas ações são sob seu ponto de vista. Não há cenas de sexo fortes e, muitas vezes, chega a ser pueril. Mas o filme foi censurado duramente, como enfatiza Veiga (2013), ficando interditado até 1980, comprometendo irremediavelmente a carreira não só do filme, mas também da cineasta, que conseguiu emplacar poucos projetos: a maioria dos projetos que apresentava era vetada. Vale lembrar que outros filmes também foram censurados no período. Toda nudez será castigada (Arnaldo Jabor, 1972) é um exemplo: com muito erotismo e cenas de nudez foi censurado, mas no ano seguinte foi liberado (Veiga, 2013). Qual o problema tão grave, afinal, de Os homens que eu tive, para ficar proibido por sete anos? Analisando documentos 
oficiais de censura, críticas e entrevistas, Veiga demonstra que a censura se deu em função da ruptura que a personagem feminina do filme promove nos papeis esperados por uma mulher:

O que parece ter chamado a atenção [...] é o comportamento de uma mulher casada e "liberada". Afinal, como essa personagem poderia desvendar ao público espectador sua intimidade e liberdade de escolha sexual com tanta naturalidade? Como uma jovem de 22 anos ousava ser a primeira diretora do cinema brasileiro no período ditatorial e ainda trazer à tona esse tipo de temática? E se as mulheres das boas famílias resolvessem pensar assim também? O "mal" teria que ser cortado pela raiz, com a tesoura moral da censura (Veiga, 2013, p. 241).

Paradoxo maior ainda parece ser a liberdade que filmes assumidamente eróticos recebiam, assim como as pornochanchadas. Nesses filmes, "as mulheres sexualmente ativas estavam em cena para serem consumidas, não para escolher ou consumir" (Veiga, 2013, p. 253). Como diz Veiga:

O projeto de governo estava voltado para a normatização da camada média brasileira, com base em normas de conduta, que acabavam submetendo as mulheres. A prova da ordem do gênero que se queria preservar nos pré-requisitos da censura está na nãorestrição às pornochanchadas, que podiam ser exibidas dentro de sua classificação etária (Veiga, 2013, p. 238).

Antes de Os homens que eu tive, Trautman dirigiu A curtição (1970), um dos episódios do longa Fantasticon: os deuses do sexo. Depois dele, realiza Dois é bom, quatro é melhor (1975), um dos episódios do longa Deliciosas traições do amor; o documentário O caso Ruschi (1977) e o bem-sucedido segundo longa metragem Sonho de menina moça (1987). Atualmente, Trautman é dona da TV por assinatura Cine Brasil TV.

\section{Feminino Plural (Vera de Figueiredo, 1976)}

O filme inicia com cena documental de um parto natural. Em posição de parir, a mulher grávida grita as dores do parto. Toda a cena está sem foco. A voz do médico tenta acalmar a mulher e lhe orienta. O médico se agita. Os gritos da parturiente aumentam. Nasce a criança. $\mathrm{O}$ médico pendura o bebê de ponta cabeça, ele chora. Exibe-se seu sexo, agora em foco. O médico diz: "é menino". 
O filme vai tratar da subjugação da mulher na sociedade. Quando nasce uma criança e o médico afirma seu sexo, a sorte está lançada. A cena parece ilustrar a ideia de performatividade de Judith Butler, desenvolvida mais de uma década depois: o acaso vai determinar se aquele ser, deve ser "forte" ou "delicado", assumindo-se como masculino ou feminino 4.

Num corte abrupto, a cena do parto é interrompida e passamos a um grupo de sete mulheres em motos numa movimentada rodovia. Percorrendo cenários reais da Baixada Fluminense, as motoqueiras seguem em direção a uma fazenda, onde são recebidas em festa por outras mulheres, homens, crianças negros, brancos, mulatos. É servida uma feijoada. Num tom alegórico, a frase solta é jogada e repetida, sempre proferida por mulheres: "as pessoas parecem ilusões maravilhosas delas mesmas; no entanto, elas existem, estão aqui". As pessoas dançam ao som de berimbau e circulam entre outras, dividindo comidas e bebidas, se confraternizando. Fim de festa, cada uma das sete motoqueiras está jogada num canto da sala, adormecida. Uma a uma, lentamente, se levanta e sai de quadro.

A mulher mais velha chega diante de um espelho, pendura sua bengala e coloca as mãos no rosto e nos cabelos, sorrindo: "venci a vida, cada ruga é uma vitória". Cantarola uma música em alemão e repete a frase sob gargalhada, admirando seu rosto refletido. Em outro ambiente, uma mulher se arrasta no chão, bate num baú e o abre. Dentro dele, outra mulher, uma negra, que se levanta, senta sob o baú e, gargalhando com a outra, diz: "você está rindo pra mim, para esse baú que me oprimiu toda a vida". Cessa a gargalhada:

Mas agora eu estou livre, estou livre do escuro, sou uma mulher livre, eu sempre quis ser livre! Eu era humilhada, humilhada como mulher e mulher negra. Quero todas as cores do mundo em mim. Está nascendo uma mulher negra livre. O que fizeram comigo a vida toda, desde criança? Minha infância, juventude [...] (Feminino Plural, 1976).

Ouve-se choro de criança. Outra mulher no chão, como se estivesse nascendo, diz com voz infantilizada:

[...] o dia mais feliz da minha vida foi o dia que eu nasci. Eu era esperada por todo mundo: por meu pai, minha mãe, todo mundo. Porque eu

4 A ideia de performatividade de Judith Butler é desenvolvida em "Problemas de gênero", publicado em 1990, e em "Corpos que pesam", de 1993. 
fui feita com amor. A coisa mais bonita do mundo é a vida. [Chora novamente e sua expressão muda, está agora apavorada, se arrasta no chão]. A morte! Um dia eu tentei o suicídio. O dia mais tenebroso da minha vida. Era horrível o lado de lá... uma gosma horrorosa, um sujo medonho. Era horrível, horrível! Socorro! (Feminino Plural, 1976).

Uma mulher deita-se ao lado de outra que está grávida e pede para que esta fale sobre o neném que vai nascer. A grávida responde: “Esse neném? Ele vai nascer livre. Livre para viver suas alegrias, suas tristezas, viver sua vida". A mulher pergunta: "Ele vai nascer dourado?". A grávida: "Dourado, igual ao sol". As outras se aproximam: "vai ser o bebê da nova era". Levantam-se alegremente, cantarolando. Entra em quadro a mulher mais recente desse grupo - o filme é circular, entendemos somente ao final que ela é Vitória, cuja história acompanhamos destacadamente. Vitória avança em direção à câmera, abre a blusa e, expondo os seios, recebe uma criança, a quem amamenta.

Acompanhamos a trajetória de Vitória, personagem central. Uma criança resiste em ser conduzida por uma mulher, tenta se desvencilhar. Uma voz off, a atormenta: "obedeça, submissa, meiga e dócil". Enquanto a criança tenta resistir, a voz continua: "a menina deve obedecer aos seus pais. À sua mãe principalmente. Ela sabe tudo o que diz e o que faz. Aprendeu tudo com os mestres e agora vai te ensinar". Na mesma sequência, a menina já maior, brinca e a voz continua:

Não reaja contra, ceda! Vem no meu caminho, obedeça. Está fazendo suas lições direitinho? Sendo boazinha? Obedecendo aos professores, obedecendo a todos? Aprendendo a ser mulher responsável, dócil e meiga? Amanhã você terá filhos e poderá ensinar tudo o que aprendeu. Por enquanto, obedeça com doçura (Feminino Plural, 1976).

Gradualmente, a criança está cada vez maior e a voz não dá trégua: "Seus irmãos podem, você não. Siga os caminhos que foram designados para você quando você nasceu mulher". Ou: "Dentro em breve, você encontrará marido e poderá ajudá-lo sempre, fazendo todas as vontades dele. Lugar de mulher é dentro de casa". Ou ainda: "Seguindo seu caminho no mundo, sem sonhar, sem ousar, sem criar". E assim, a voz continua em todos os estágios da vida a orientar o destino irremediavelmente traçado para sua vida. Não deixa de ser uma 
ironia a mais que a voz seja da Rose Marie Muraro, uma das maiores intelectuais feministas do país.

A criança agora é uma moça. Numa só cena extremamente elaborada, a vida de Vitória dá saltos elípticos: ela recebe o diploma, surge o homem que quer casar com ela. Sua vida segue o curso "normal": casa-se, engravida, tem filho, cuida do lar. Ela se angustia. A voz de Muraro não a abandona: "seja obediente, submissa, meiga e dócil". Vitória foge, sai em disparada pelas ruas da cidade, quer escapar da voz que a aprisiona. Um policial tenta lhe segurar, ela escapa. Pega uma britadeira em mãos. Em fúria, perfura um concreto. Corre, sobe numa rampa e vomita. A imagem congela. Depois de um longo trecho escuro, Vitória ressurge renovada, sorrindo, com panos vermelhos esvoaçantes, dançando ao som de um samba. Na cena seguinte, a vemos entre as demais mulheres. Todas com panos brancos sob o corpo estão numa espécie de floresta paradisíaca.

É onírico o ambiente, a estrutura é alegórica. Não se trata de narrativa convencional. Não há uma interpretação única para Feminino Plural, que ainda traz outras histórias, além da de Vitória, mas sempre em torno daquele grupo. Os elementos do feminismo estão vivíssimos.

Vera de Figueiredo iniciou-se na direção através da bitola super 8, em 1972. Já em 35 mm, realiza com Zózimo Bulbul, o curta Artezanato do samba (1974) e em 1979, dirige O mestre sala. Samba da criação do mundo (1980) é seu segundo longa de ficção. Feminino Plural é seu primeiro longa e repercutiu nos principais suplementos culturais do país. Participou do Festival de Cannes, em 1977. Participou também no Festival de Taormina, na Sicília, e foi convidado para o New York Film Festival, no mesmo ano. No entanto, poucos conhecem o filme no Brasil. Somente em 2006, a TVE exibiu o filme e, em 2011, o Festival Internacional de Curtas de São Paulo o homenageou por seus 35 anos (Cavalcante e Holanda, 2013). Na década de 1990, Vera de Figueiredo realiza ainda dois filmes, o média Amazônia como metáfora (1992) e o curta Craque Cultura (1997), de acordo com o catálogo Documentário Brasileiro.

\section{Considerações finais}

Vimos que as mulheres produziram bem menos que os homens, sobretudo no início do chamado cinema moderno brasileiro, já que a partir dos 1970 a participação delas na direção aumenta consideravelmente, sobretudo em documentários. Se nos anos 1960 encontramos apenas oito documentários feitos exclusivamente por mulheres, para ficarmos com a fonte do catálogo Documentário Brasileiro, nos anos 1970 esse número já salta para 154 e entre os anos 2000 e 2009, passa para 319. De toda forma, vale realçar: a produção é ainda bem menor que a masculina, que assina o dobro de documentários 
nessa última década considerada. Outra constatação é que os filmes dirigidos por mulheres, mesmo que tragam elementos estilísticos e temáticos fortes na época em que foram produzidos, como é o caso dos três filmes aqui destacados, a história do cinema brasileiro não lhes deu merecida atenção.

Buscando compreender esse desequilíbrio, trouxemos um panorama sobre a secular discriminação da mulher na sociedade, que tentava se justificar em injustificadas ideias de natureza e divindade, passando por Aristóteles, pela teologia, pelo direito, pela literatura. Da mesma forma, é também secular a resistência das mulheres a essa subjugação. Resistência que lhes custaram punições, desprezo e ridicularizações, o que não lhes inibiu a participar de quase todas as áreas ao longo da história. Na literatura, é grande o número de estudos que buscam resgatar escritoras soterradas pela história. O cinema, embora seja a mais recente das artes, já acumula histórias de cineastas esquecidas ou que foram pouco estudadas, mesmo que suas obras sejam carregadas de inventividade, vigor e ousadia, como demonstram os filmes acima discutidos.

Por que destacar o cinema feito por mulheres? Na história do cinema em geral já não estaria contemplada a história do cinema feito por elas? Pensamos que não. E para fundamentar, trouxemos a discussão travada na disciplina "história", que desenvolveu um campo de estudo dentro da disciplina, a "história das mulheres", justamente para abranger a metade da humanidade excluída. Ao criticar a visão dominante (masculina), a história das mulheres abalou padrões tradicionalmente adotados pela história, como, por exemplo, considerar sujeito universal o homem branco. A oposição homem/mulher, no entanto, foi importante para demarcar esse campo da história e para os estudos feministas, mas num segundo momento, mostrou-se limitada, afinal nem todas as mulheres estavam reunidas sob as mesmas questões, os interesses eram variados. Além disso, considerava-se importante, desde os anos 1980, que o sujeito fosse compreendido nas relações também de raça e classe, não só na sexual. Do contrário, esse potencial epistemológico do pensamento feminista sofreria o risco de ser conformado sob o discurso patriarcal. Assim, o que se sugere é que seja criado um conceito de gênero que não seja baseado tanto na diferença sexual. O processo é complexo e dinâmico, não se encerraria aqui, mas acreditamos que o avanço dos estudos do cinema feito por mulheres possa também contribuir no andar dessa discussão.

\section{Referências bibliográficas}

BADINTER, Elisabeth. Um amor conquistado: o mito do amor materno. Rio de Janeiro: Nova Fronteira, 1985. 
BEAUVOIR, Simone. O segundo sexo: fatos e mitos. São Paulo: Difusão Europeia do Livro, 1970.

CATÁLOGO DO DOCUMENTÁRIO BRASILEIRO. Disponível em: < documentariobrasileiro. org >. Acesso em: 10 mar. 2016.

CAVALCANTE, Alcilene; HOLANDA, Karla. Feminino Plural: história, gênero e cinema no Brasil dos anos 1970. In: BRAGANÇA, Maurício de; TEDESCO, Marina (orgs). Corpos em projeção: gênero e sexualidade no cinema latino-americano. Rio de Janeiro, 7 Letras, 2013. p. 134-152.

DE LAURETIS, Teresa. A tecnologia do gênero. In: HOLLANDA, Heloisa Buarque de (org.). Tendências e impasses: o feminismo como crítica da cultura. Rio de Janeiro: Rocco, 1994, p. 206-242.

FRIEDAN, Betty. Mística feminina. Petrópolis/RJ: Vozes, 1971.

HOLANDA, Karla. Documentaristas brasileiras e as vozes feminina e masculina. In Significação - Revista de Cultura Audiovisual. São Paulo, v. 42, n. 44. p. 339-358, dez. 2015. Disponível em: <http://revistas.usp.br/significacao/article/ view/103434/106942>. Acesso em: 10 mar. 2016.

PEREIRA, Ana Catarina dos Santos. A mulher cineasta: da arte pela arte a uma estética da diferenciação. 2014. 357 f. Tese (Doutorado em Ciências da Comunicação). Universidade da Beira Interior. Covilhã (Portugal), 2014.

SCOTT, Joan. História das mulheres. In: BURKE, Peter. A escrita da história: novas perspectivas. São Paulo: Editora da Universidade Estadual Paulista, 1992, p. 6395.

TAVARES, Mariana. Helena Solberg: do cinema novo ao documentário contemporâneo. São Paulo, Imprensa Oficial, 2014.

TELLES, Norma. Encantações: escritoras e imaginação literária no Brasil, século XIX. São Paulo: Intermeios, 2012.

VEIGA, Ana Maria. Cineastas brasileiras em tempos de ditadura: cruzamentos, fugas, especificidades. 2013. 397 f. Tese (Doutorado em História Cultural) Universidade Federal de Santa Catarina, Florianópolis, 2013.

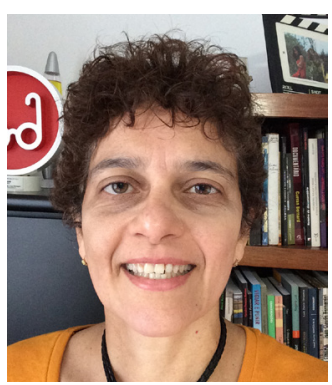

Recebido em: 22/6/2016

Aceito em: 13/7/2016

Endereço da autora:

Karla Holanda $<$ holanda.k@gmail.com $>$

Instituto de Artes e Design da Universidade Federal de Juiz de Fora

Campus Universitário - Bairro Martelos

36036-330 - Juiz de Fora - MG - Brasil 